\title{
Erratum to: Civil society research and Marcellus Shale natural gas development: results of a survey of volunteer water monitoring organizations
}

Kirk Jalbert • Abby J. Kinchy • Simona L. Perry

Published online: 22 January 2014

(C) AESS 2014

Erratum to: J Environ Stud Sci

DOI 10.1007/s13412-013-0155-7

The original version of this article unfortunately contained a mistake. The authors missed to include the following text as Acknowledgement.

"This material is based upon work supported by the National Science Foundation under Grant No. 1126235."

The online version of the original article can be found at http://dx.doi.org/ 10.1007/s13412-013-0155-7.

K. Jalbert $(\bowtie) \cdot$ A. J. Kinchy

Science and Technology Studies Department, Rensselaer

Polytechnic Institute, 110 Eighth Street, Troy, NY 12180, USA

e-mail: jalbek@rpi.edu

S. L. Perry

c.a.s.e. Consulting Services, 9810 Dairyton Court, Montgomery

Village, MD 20886, USA 